\title{
Morphological features of the Carniolan (Apis mellifera carnica Pollm) and Carpathian (Apis mellifera carpatica) breeds of honey bees
}

\author{
Boymakhmat Kakhramanov ${ }^{1 *}$, Solikh Isamukhamedov ${ }^{1}$, Feruza Safarova ${ }^{1}$, Khusniddin \\ Donaev $^{1}$, and Fakhriddin Mamadov ${ }^{1}$ \\ ${ }^{1}$ Tashkent State Agrarian University, 100140 Tashkent province, Uzbekistan
}

\begin{abstract}
This article presents the results of a study of the Carniolan (Apis mellifera carnica Pollm) and Carpathian (Apis mellifera carpatica) breeds of honey bees and their crossbred populations in the conditions of the Tashkent province in Uzbekistan. The morphological characteristics of bees were revealed, morphometric measurements and analysis of economically useful traits were carried out. A comparative analysis of the morphological and morphometric differences of the bee breeds under study has been carried out.
\end{abstract}

\section{Introduction}

The life of a honey bee is closely related to its morphology. Morphology studies the structure of the bee's body and its organs. Knowledge of the life and work of a bee colony is important not only for the correct use of bees for economic purposes, but also for changing their nature in order to create highly productive bee breeds [1].

The most common method for determining the species of bees is the method of morphological assessment, which consists in a comparative study of their exterior characteristics [2].

For the study of morphometric indicators, 3 groups of bees were formed into two experiments (Carniolan and Carpathian bee breeds and 1-control-their hybrids). The studies were carried out in accordance with the guidelines of the Research Institute of Beekeeping $[3,4]$.

The study of morphometric characteristics of worker bees was carried out according to the method of BB Alpatov [5].

In accordance with the recommendations of the Research Institute of Beekeeping, the number of bees in the sample for studying the exterior was 50 individuals. The analyzes were carried out by the Beekeeping Laboratory at the Tashkent State Agrarian University in Uzbekistan [6-8].

A number of authors [8-10] have established that the indicators of exterior signs vary widely in different breeds. Each breed is characterized by separate metric indicators, indices that show the ratio of these characteristics.

\footnotetext{
* Corresponding author: b.kaxramanov@mail.ru
} 


\section{Materials and methods}

The following morphometric parameters were analyzed: proboscis length and width of the right fore wing, cubital and tarsal indices.

The cubital index was determined using the following equation (1) [9]:

$$
\mathrm{K}=\text { vein length }(a) / \text { vein length }(b) \times 100 \%
$$

The tarsal index was determined according to the following equation (2):

$$
\mathrm{K}=\mathrm{W} / \mathrm{L} \times 100 \%
$$

where, W-width of the first segment of the hind tarsus (b) and L-length of the first segment of the hind tarsus (a).

After the selection of the bees, they were killed with boiling water. Then each sample was placed in a gauze bag and poured with $70 \%$ ethanol and fixed. At the same time, only one colony of bees was kept in each jar. Exterior features were measured under an MBS-10 binocular microscope using an eyepiece-micrometer ruler.

At x10 magnification, the wing length was measured, and the dimensions of other parameters at x20 magnification. Exterior signs were studied using temporary glycerol preparations.

The following exterior parameters of honey bees were used for morphometric analysis:

1. Cubital index - defined as the ratio of the vein length (a) of the third cubital cell to the vein length (b), expressed as a percentage (Fig. 1).

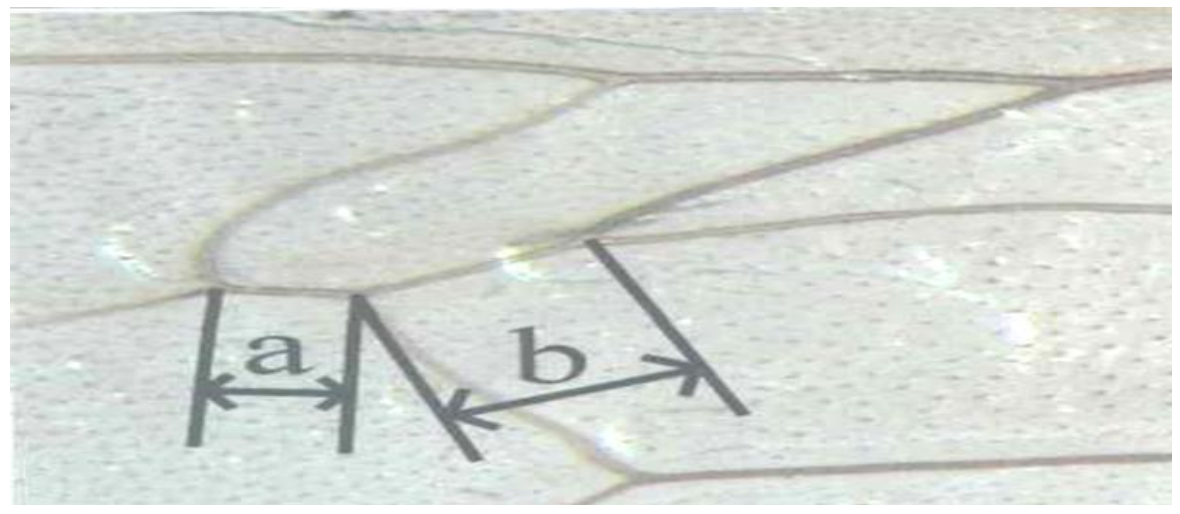

Fig. 1. Length of the veins of the third cubital cell of the front wing of a honey bee [22].

2. Tarsal index, calculated as the ratio of the width of the first segment of the hind tarsus (b) to its length (a), expressed as a percentage (Fig. 2).

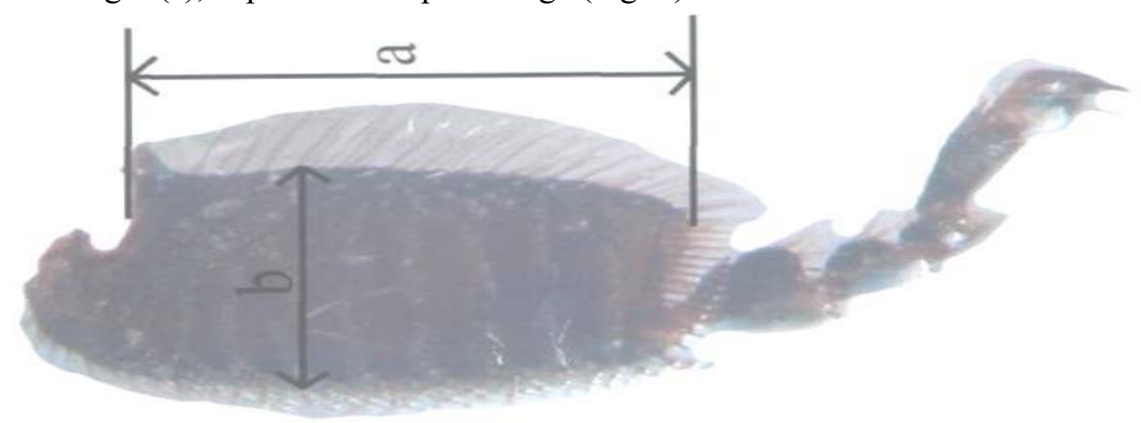

Fig. 2. The first segment of the hind leg of a honey bee [9]. 
3. The length of the proboscis of a honey bee, which is the sum of the distances $a$ and $b$ (Fig. 3).

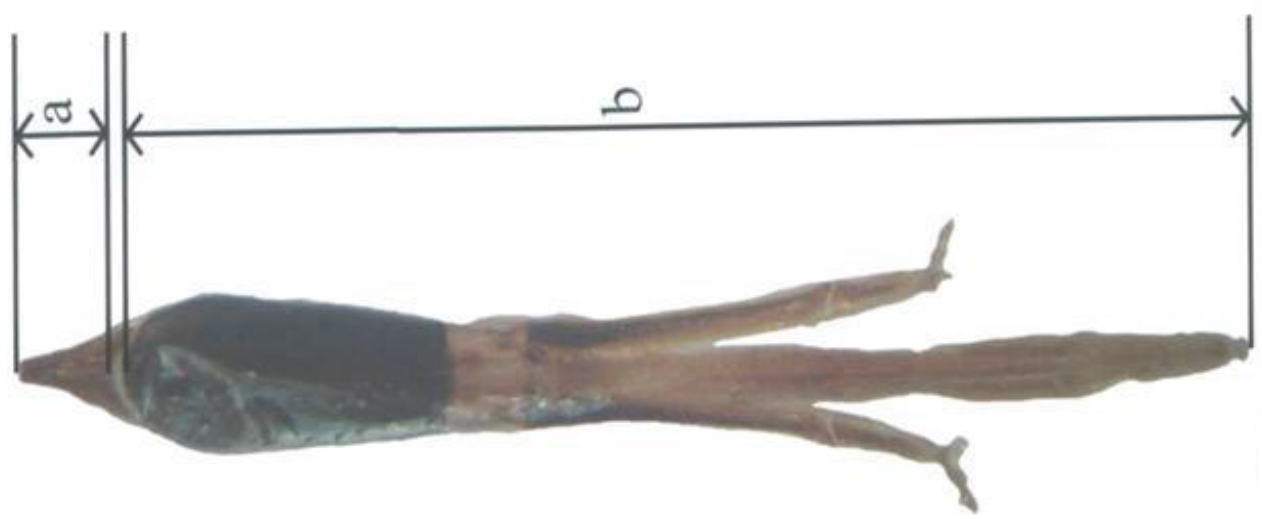

Fig. 3. The proboscis of a honey bee [9].

The length of the proboscis was determined according to the following equation (3):

$$
a+b=a+b
$$

where, $a$ - the length of the base of the proboscis and $b$ - the total length of the proboscis.

The obtained data were subjected to statistical processing by methods of variation statistics with verification of the reliability of the results using the Student's test and the level of significance (P) according to the method of Merkuryeva EK [10], calculating the correlation on a personal computer using MS OFFICE (Microsoft Excel) programs.

\section{Results and discussion}

We used cubital and tarsal indices and proboscis length as the most objective signs reflecting the exterior features of bees.

The average value of the vein length a of the third cubital cell of the fore wing in the samples of the Carniolan bee breed was $19.04 \pm 1.1 \mathrm{~mm}$ with the coefficient of variation $\mathrm{Cv}$ - 4.2\% ( $\mathrm{P}>0.999)$, and the minimum and maximum values of the vein length a was 11.2 and $29.23 \mathrm{~mm}$, respectively (Table 1 ).

The average value of the vein length a of Carpathian bees was $18.15 \pm 1.0 \mathrm{~mm}$ at $\mathrm{Cv}$ $4.6 \%,(\mathrm{P}>0.999)$ the minimum value is $11.5 \mathrm{~mm}$, the maximum value is $27.7 \mathrm{~mm}$.

The average value of this indicator of the crossbred bee population was $16.15 \pm 0.85$ $\mathrm{mm}$ at $\mathrm{Cv}-4.1 \%$, the minimum and maximum values are $11.5 \mathrm{~mm}$ and $21.4 \mathrm{~mm}$, respectively.

The average value of the vein length $b$ of the third cubital cell of the fore wing in the samples of the Carniolan breed of bees was $37.8 \pm 1.0 \mathrm{~mm}$ at $\mathrm{Cv}-4.73 \%(\mathrm{P}>0.999)$. The minimum is $21.2 \mathrm{~mm}$, and the maximum value is $38.4 \mathrm{~mm}$.

The average value of this indicator in the Carpathian bees was $37.33 \pm 1.25 \mathrm{~mm}$ at $\mathrm{Cv}-$ $5.25 \%(\mathrm{P}>0.999)$. The maximum and minimum values are 21.2 and $47.6 \mathrm{~mm}$, respectively.

The average value of the vein length $b$ of the crossbred bee population is $35.86 \pm 0.95$ $\mathrm{mm}$ at $\mathrm{Cv}-4.95 \%$, the maximum and minimum values are $48.9 \mathrm{~mm}$ and $23.2 \mathrm{~mm}$, respectively.

The greatest value of the cubital index of $50.37 \pm 1.1 \%$ at $\mathrm{Cv}-5.21 \%$ belongs to the Carniolan bees, which testifies to the correspondence of this value to this breed $(\mathrm{P}>0.999)$. 
Table 1. Indicators of the cubital index of bees of different breeds (n-50).

\begin{tabular}{|c|c|c|c|c|c|c|c|c|}
\hline$\#$ & $\begin{array}{c}\text { Honey bee } \\
\text { groups }\end{array}$ & $\begin{array}{c}\text { Vein } \\
\text { length (a), } \\
\text { mm } \\
(\text { Lim }) \mathrm{M} \pm \mathrm{m}\end{array}$ & $\mathrm{Cv}, \%$ & $\begin{array}{c}\text { Vein } \\
\text { length (b), } \\
\text { mm (Lim) } \\
\mathrm{M} \pm \mathrm{m}\end{array}$ & $\begin{array}{l}\text { Cv, } \\
\%\end{array}$ & $\begin{array}{c}\text { Cubital } \\
\text { index, \% } \\
\text { (Lim) } \mathrm{M} \pm \mathrm{m}\end{array}$ & $\begin{array}{l}\text { Cv, } \\
\%\end{array}$ & $\begin{array}{c}\text { Relative } \\
\text { to the } \\
\text { control. } \\
\%\end{array}$ \\
\hline & $\begin{array}{c}\text { Apis } \\
\text { mellifera } \\
\text { carnica } \\
\text { Pollm), first } \\
\text { year }\end{array}$ & $\begin{array}{c}(11.2-27.3) \\
18.62 \pm 1.4\end{array}$ & 4.1 & $\begin{array}{c}(21.2-47.6) \\
37.2 \pm 1.1\end{array}$ & 4.62 & $\begin{array}{c}(39.2-56.6) \\
49.98 \pm 1.2\end{array}$ & 4.92 & 105 \\
\hline 1 & $\begin{array}{c}\text { Apis } \\
\text { mellifera } \\
\text { carnica } \\
\text { Pollm, } \\
\text { second year }\end{array}$ & $\begin{array}{c}(12.1- \\
29.23) \\
19.46 \pm 1.1\end{array}$ & 4.3 & $\begin{array}{c}(29.2-48.6) \\
38.4 \pm 1.2\end{array}$ & 4.84 & $\begin{array}{c}(49.2-53.2) \\
50.67 \pm 1.3\end{array}$ & 5.5 & 106.8 \\
\hline & Average & $19.04 \pm 1.1$ & 4.2 & $37.8 \pm 1.0$ & 4.73 & $50.37 \pm 1.1$ & 5.21 & 111.8 \\
\hline \multirow{3}{*}{2} & $\begin{array}{c}\text { Apis } \\
\text { mellifera } \\
\text { carpatica, } \\
\text { first year }\end{array}$ & $\begin{array}{c}(11.5-23.4) \\
17.46 \pm 0.9\end{array}$ & 4.7 & $\begin{array}{c}(21.2-41.7) \\
36.84 \pm 1.4\end{array}$ & 5.1 & $\begin{array}{c}(41.2-52.2) \\
47.39 \pm 1.1\end{array}$ & 4.8 & 108.8 \\
\hline & $\begin{array}{c}\text { Apis } \\
\text { mellifera } \\
\text { carpatica, } \\
\text { second year }\end{array}$ & $\begin{array}{c}(11.6-27.7) \\
18.84 \pm 1.1\end{array}$ & 4.55 & $\begin{array}{c}(26.2-47.6) \\
37.82 \pm 1.1\end{array}$ & 5.4 & $\begin{array}{c}(45.2-52.3) \\
49.8 \pm 1.0\end{array}$ & 5.2 & 106.8 \\
\hline & Average & $\begin{array}{l}18.15 \pm 1.0 \\
\end{array}$ & 4.6 & $37.33 \pm 1.25$ & 5.25 & $48.62 \pm 0.95$ & 5.0 & 107.8 \\
\hline \multirow{3}{*}{3} & $\begin{array}{c}\text { Mixed } \\
\text { population } \\
\text { of bees in } \\
\text { the first year }\end{array}$ & $\begin{array}{c}(11.5-21.4) \\
16.19 \pm 1.2\end{array}$ & 3.9 & $\begin{array}{c}(23.2-47.6) \\
35.62 \pm 1.2\end{array}$ & 4.8 & $\begin{array}{c}(43.3-47.5) \\
45.4 \pm 1.2\end{array}$ & 4.2 & 103 \\
\hline & $\begin{array}{c}\text { Mixed } \\
\text { population } \\
\text { of bees in } \\
\text { the second } \\
\text { year }\end{array}$ & $\begin{array}{c}(11.5-21.4) \\
16.12 \pm 0.7\end{array}$ & 4.3 & $\begin{array}{c}(23.4-48.9) \\
36.11 \pm 0.9\end{array}$ & 5.1 & $\begin{array}{c}(43.0-45.5) \\
44.6 \pm 1.1\end{array}$ & 4.7 & 97 \\
\hline & Average & $16.15 \pm 0.85$ & 4.1 & $35.86 \pm 0.95$ & 4.95 & $45.03 \pm 1.15$ & 4.45 & 100 \\
\hline
\end{tabular}

The cubital index of bees of the Carpathian breed is $48.62 \pm 0.95 \%$ at $\mathrm{Cv}-5 \%$, $(\mathrm{P}>$ 0.999 ). The minimum values of this indicator are $41.2 \%$, the maximum $-52.3 \%$.

The average value of the cubital index of the crossbred bee population is $45.03 \pm 1.15 \%$ at $\mathrm{Cv}-4.45 \%$, the minimum values are $43 \%$, and the maximum ones are $47.5 \%$.

The average value of the vein length a of the third cubital cell of the fore wing in the samples of the Carniolan bee breed was $19.04 \pm 1.1 \mathrm{~mm}$ with the coefficient of variation $\mathrm{Cv}$ - 4.2\%, ( $>0.999)$ the minimum and maximum values of the vein length a was 11.2 and $29.23 \mathrm{~mm}$, respectively (Table 2 ).

The average value of the vein length a of Carpathian bees was $18.15 \pm 1.0 \mathrm{~mm}$ at $\mathrm{Cv}$ $4.6 \%(\mathrm{P}>0.999)$, and the minimum value is $11.5 \mathrm{~mm}$, the maximum value is $27.7 \mathrm{~mm}$.

The average value of this indicator of the crossbred bee population was $16.15 \pm 0.85$ $\mathrm{mm}$ at $\mathrm{Cv}-4.1 \%$, the minimum and maximum values are $11.5 \mathrm{~mm}$ and $21.4 \mathrm{~mm}$, respectively.

The average value of the vein length $b$ of the third cubital cell of the fore wing in the samples of the Carniolan breed of bees was $37.8 \pm 1.0 \mathrm{~mm}$ at $\mathrm{Cv}-4.73 \%(\mathrm{P}>0.999)$. The minimum is $21.2 \mathrm{~mm}$, and the maximum value is $38.4 \mathrm{~mm}$.

The average value of this indicator in the Carpathian bees was $37.33 \pm 1.25 \mathrm{~mm}$ at $\mathrm{Cv}-$ $5.25 \%$, $(\mathrm{P}>0.999)$. The maximum and minimum values are 21.2 and $47.6 \mathrm{~mm}$, respectively. 
The average value of the vein length $b$ of the crossbred bee population is $35.86 \pm 0.95$ $\mathrm{mm}$ at $\mathrm{Cv}-4.95 \%$, the maximum and minimum values are $48.9 \mathrm{~mm}$ and $23.2 \mathrm{~mm}$, respectively.

The greatest value of the cubital index of $50.37 \pm 1.1 \%$ at $\mathrm{Cv}-5.21 \%$ belongs to the Carniolan bees, which testifies to the correspondence of this value to this breed $(\mathrm{P}>0.999)$.

The cubital index of bees of the Carpathian breed is $48.62 \pm 0.95 \%$ at $\mathrm{Cv}-5 \%$, ( $>$ 0.999). The minimum values of this indicator are $41.2 \%$, the maximum $-52.3 \%$.

The average value of the cubital index of the crossbred bee population is $45.03 \pm 1.15 \%$ at $\mathrm{Cv}-4.45 \%$, the minimum values are $43 \%$, and the maximum ones are $47.5 \%$.

Table 2. Indicators of the tarsal index of bees of different breeds ( $n-50)$.

\begin{tabular}{|c|c|c|c|c|c|c|c|c|}
\hline$\#$ & $\begin{array}{c}\text { Honey bee } \\
\text { groups }\end{array}$ & $\begin{array}{l}\text { Length of } \\
\text { the first } \\
\text { segment of } \\
\text { the hind } \\
\text { tarsus, mm } \\
\text { (Lim) } \mathrm{M} \pm \mathrm{m}\end{array}$ & $\mathrm{Cv}, \%$ & $\begin{array}{l}\text { Width of } \\
\text { the first } \\
\text { segment of } \\
\text { the hind } \\
\text { tarsus, mm } \\
\text { (Lim) } \mathrm{M} \pm \mathrm{m}\end{array}$ & $\mathrm{Cv}, \%$ & $\begin{array}{c}\text { Tarsal } \\
\text { index, \% } \\
\text { (Lim) } \mathrm{M} \pm \mathrm{m}\end{array}$ & $\mathrm{Cv}, \%$ & $\begin{array}{c}\text { Relative } \\
\text { to the } \\
\text { control, } \\
\%\end{array}$ \\
\hline \multirow{3}{*}{1} & $\begin{array}{c}\text { Apis mellifera } \\
\text { carnica } \\
\text { Pollm), first } \\
\text { year }\end{array}$ & $\begin{array}{l}(2.1-6.1) \\
4.20 \pm 1.3\end{array}$ & 2.3 & $\begin{array}{l}(1.1-3.7) \\
2.40 \pm 1.3\end{array}$ & 2.04 & $\begin{array}{c}(45.1-61.7) \\
57.1 \pm 1.2\end{array}$ & 2.64 & 107 \\
\hline & $\begin{array}{c}\text { Apis mellifera } \\
\text { carnica } \\
\text { Pollm, second } \\
\text { year } \\
\end{array}$ & $\begin{array}{c}(2.4-6.11) \\
4.22 \pm 1.1\end{array}$ & 2.6 & $\begin{array}{c}(1.14-3.7) \\
2.42 \pm 1.1\end{array}$ & 2.2 & $\begin{array}{c}(45.1-61.5) \\
57.3 \pm 1.0\end{array}$ & 2.78 & 107.4 \\
\hline & Average & $4.21 \pm 1.1$ & 2.45 & $2.41 \pm 1.2$ & 2.12 & $57.2 \pm 1.1$ & 2.71 & 107.2 \\
\hline \multirow{3}{*}{2} & $\begin{array}{c}\text { Apis mellifera } \\
\text { carpatica, first } \\
\text { year } \\
\end{array}$ & $\begin{array}{c}(3.21-5.15) \\
4.18 \pm 1.1\end{array}$ & 2.4 & $\begin{array}{c}(1.24-3.44) \\
2.34 \pm 1.2\end{array}$ & 2.0 & $\begin{array}{c}(42.1-61.5) \\
55.98 \pm 1.6\end{array}$ & 2.1 & 102.8 \\
\hline & $\begin{array}{l}\text { Apis mellifera } \\
\text { carpatica, } \\
\text { second year }\end{array}$ & $\begin{array}{c}(3.28-5.14) \\
4.21 \pm 1.2\end{array}$ & 2.8 & $\begin{array}{c}(1.24-3.45) \\
2.35 \pm 1.1\end{array}$ & 2.6 & $\begin{array}{c}(42.1-60.5) \\
55.81 \pm 1.2\end{array}$ & 2.9 & 106 \\
\hline & Average & $4.19 \pm 1.15$ & 2.6 & $2.345 \pm 1.15$ & 2.3 & $55.96 \pm 1.1$ & 2.5 & 104.8 \\
\hline \multirow{3}{*}{3} & $\begin{array}{l}\text { Mixed } \\
\text { population of } \\
\text { bees in the } \\
\text { first year }\end{array}$ & $\begin{array}{l}(3.4-5.0) \\
4.02 \pm 1.3\end{array}$ & 2.2 & $\begin{array}{c}(1.14-3.14) \\
2.14 \pm 1.1\end{array}$ & 2.4 & $\begin{array}{c}(42.1-64.5) \\
53.23 \pm 1.2\end{array}$ & 2.0 & 98 \\
\hline & $\begin{array}{c}\text { Mixed } \\
\text { population of } \\
\text { bees in the } \\
\text { second year }\end{array}$ & $\begin{array}{l}(3.4-5.1) \\
4.06 \pm 0.9\end{array}$ & 2.5 & $\begin{array}{c}(1.14-3.18) \\
2.18 \pm 1.4\end{array}$ & 2.8 & $\begin{array}{c}(42.51- \\
64.67) \\
53.69 \pm 1.3\end{array}$ & 2.6 & 102 \\
\hline & Average & $4.04 \pm 1.1$ & 2.35 & $2.16 \pm 1.25$ & 2.6 & $53.4 \pm 1.25$ & 2.3 & 100 \\
\hline
\end{tabular}

The average value of the length of the first segment of the hind leg of the Carniolan breed was $4.21 \pm 1.1 \mathrm{~mm}$ with $\mathrm{Cv}-2.45 \%$, the minimum and maximum values are $2.1 \mathrm{~mm}$ and $6.11 \mathrm{~mm}$, respectively (Table 3).

In bees of the Carpathian breed, the average value of this indicator is $4.19 \pm 1.15 \mathrm{~mm}$, with $\mathrm{Cv}-2.6 \%$, the minimum values are $-3.21 \mathrm{~mm}$, the maximum $-5.15 \mathrm{~mm}$.

The average values of this indicator in the crossbred population of bees are $4.04 \pm 1.1$ $\mathrm{mm}$, with $\mathrm{Cv}-2.35 \%$, the minimum values are $-3.4 \mathrm{~mm}$, the maximum $-5.1 \mathrm{~mm}$.

The average value of the width of the first segment of the hind leg of the Carniolan breed was $2.41 \pm 1.2 \mathrm{~mm}$ with $\mathrm{Cv}-2.12 \%$, the minimum and maximum values are $1.1 \mathrm{~mm}$ and $3.7 \mathrm{~mm}$, respectively.

The average value of the width of the first segment of the hind leg of the Carpathian bees was $2.34 \pm 1.15 \mathrm{~mm}$ at $\mathrm{Cv}-2.3 \%$, the minimum value is $1.24 \mathrm{~mm}$, the maximum value is $3.45 \mathrm{~mm}$. 
The average value of the width of the first segment of the hind leg in the crossbred population of bees was $2.16 \pm 1.25 \mathrm{~mm}$ with $\mathrm{Cv}-2.6 \%$, the minimum value was $1.14 \mathrm{~mm}$, and the maximum value was $3.18 \mathrm{~mm}$.

The Carniolan bee breeds have the highest tarsal index, which is their breed peculiarity. The tarsal index corresponded to the bees of the Carniolan breed, which was $57.2 \pm 1.1 \%$, with $\mathrm{Cv}-2.71 \%(\mathrm{P}>0.999)$. The minimum values of this indicator are $45.1 \%$, and the maximum $-61.7 \%$.

The value of this indicator of bees of the Carpathian breed is $55.96 \pm 1.1 \%$ at $\mathrm{Cv}-2.5 \%$, $(\mathrm{P}>0.999)$. The minimum and maximum values are $42.1 \%$ and $61.5 \%$, respectively.

The average value of the tarsal index of the hybrid population of bees was $53.4 \pm 1.25 \%$ with the coefficient of variation $\mathrm{Cv}-2.3 \%$, the minimum value of the tarsal index was $42.1 \%$, and the maximum was $64.67 \%$.

The length of the proboscis is a quantitative characteristic and the trait is obtained by adding three measurements. This feature is necessary when determining the species of bees. It also has an independent selection, biological and economic value: bees with a longer proboscis are able to deliver nectar from the nectaries of flowers located deeper. To a large extent, it is subject to seasonal changes, which must be taken into account in order to avoid errors [10].

The average indicators of proboscis length in bees of the Carniolan breed corresponded to $6.45 \pm 1.4 \mathrm{~mm}$ with a coefficient of variation $\mathrm{Cv}-3.5 \%$, ( $\mathrm{P}>0.999)$. The minimum and maximum values of the proboscis length were $5.22 \mathrm{~mm}$ and $6.81 \mathrm{~mm}$, respectively.

The average value of the proboscis length in Carpathian bees is $6.7 \pm 1.3 \mathrm{~mm}$ at $\mathrm{Cv}$ $3.4 \%,(\mathrm{P}>0.999)$. The minimum values for the length of the proboscis correspond to 5.34 $\mathrm{mm}$, the maximum $-6,94 \mathrm{~mm}$.

The average value of the proboscis length of the hybrid population of bees was $5.58 \pm$ $1.7 \mathrm{~mm}$ with the coefficient of variation $\mathrm{Cv}-3.4 \%$. The minimum and maximum values of the proboscis length are $4.96 \mathrm{~mm}$ and $6.68 \mathrm{~mm}$, respectively.

Table 3. Indicators of proboscis length of bees of different breeds $(n-50)$.

\begin{tabular}{|c|c|c|c|c|c|c|c|c|}
\hline \# & $\begin{array}{c}\text { Honey bee } \\
\text { groups }\end{array}$ & $\begin{array}{c}\text { Proboscis } \\
\text { length } \\
\text { (a), mm } \\
\mathrm{M} \pm \mathrm{m}\end{array}$ & $\mathrm{Cv}, \%$ & $\begin{array}{l}\text { Proboscis } \\
\text { length }(b) \text {, } \\
\text { mm } \mathrm{M} \pm \mathrm{m}\end{array}$ & $\mathrm{Cv}, \%$ & $\begin{array}{c}\text { Proboscis } \\
\text { length } \\
(\mathbf{a}+\mathbf{b}), \mathbf{m m} \\
\text { (Lim) } \mathrm{M} \pm \mathrm{m}\end{array}$ & $\mathrm{Cv}, \%$ & $\begin{array}{c}\text { Relative } \\
\text { to the } \\
\text { control, } \\
\%\end{array}$ \\
\hline \multirow{3}{*}{1} & $\begin{array}{c}\text { Apis mellifera } \\
\text { carnica Pollm), } \\
\text { first year }\end{array}$ & $0.50 \pm 0.3$ & 3.0 & $5.92 \pm 1.4$ & 3.9 & $\begin{array}{c}(5.11-6.78) \\
6.42 \pm 1.6\end{array}$ & 3.6 & 118 \\
\hline & $\begin{array}{l}\text { Apis mellifera } \\
\text { carnica Pollm, } \\
\text { second year }\end{array}$ & $0.52 \pm 0.7$ & 3.4 & $5.96 \pm 1.6$ & 3.7 & $\begin{array}{c}(5.22-6.81) \\
6.48 \pm 1.3\end{array}$ & 3.4 & 114 \\
\hline & Average & $0.51 \pm 0.5$ & 3.2 & $5.94 \pm 1.5$ & 3.8 & $6.45 \pm 1.4$ & 3.5 & 116 \\
\hline \multirow{3}{*}{2} & $\begin{array}{c}\text { Apis mellifera } \\
\text { carpatica, first } \\
\text { year }\end{array}$ & $0.54 \pm 0.6$ & 3.6 & $6.14 \pm 1.5$ & 3.4 & $\begin{array}{c}(5.12-6.4) \\
6.68 \pm 1.1\end{array}$ & 3.2 & 115 \\
\hline & $\begin{array}{l}\text { Apis mellifera } \\
\text { carpatica, } \\
\text { second year }\end{array}$ & $0.52 \pm 0.5$ & 3.2 & $6.20 \pm 1.6$ & 3.9 & $\begin{array}{c}(5.34-6.94) \\
6.72 \pm 1.2\end{array}$ & 3.7 & 125 \\
\hline & Average & $0.53 \pm 0.5$ & 3.4 & $6.17 \pm 1.5$ & 3.65 & $6.7 \pm 1.3$ & 3.4 & 120 \\
\hline \multirow{3}{*}{3} & $\begin{array}{c}\text { Mixed } \\
\text { population of } \\
\text { bees in the first } \\
\text { year }\end{array}$ & $0.48 \pm 0.4$ & 3.8 & $5.14 \pm 1.1$ & 3.3 & $\begin{array}{l}(5.0-6.8) \\
5.62 \pm 1.8\end{array}$ & 3.6 & 95 \\
\hline & $\begin{array}{l}\text { Mixed } \\
\text { population of } \\
\text { bees in the } \\
\text { second year }\end{array}$ & $0.46 \pm 0.3$ & 3.5 & $5.09 \pm 1.3$ & 3.8 & $\begin{array}{c}(4.96-6.68) \\
5.55 \pm 1.6\end{array}$ & 3.3 & 105 \\
\hline & Average & $0.47 \pm 0.3$ & 3.65 & $5.11 \pm 1.2$ & 3.55 & $5.58 \pm 1.7$ & 3.4 & 100 \\
\hline
\end{tabular}




\section{Conclusions}

The morphological characteristics of the studied experimental bees correspond to the standards of the Carniolan (Apis mellifera carnica Pollm) and Carpathian (Apis mellifera carpatica) breeds: the cubital index in the Carniolan breeds is $50.37 \%$ on average, the tarsal index is $57.2 \%$, the proboscis length is $6.45 \mathrm{~mm}$, respectively, among the Carpathian bee breeds $48.62 \%, 55.96 \%, 6.7 \mathrm{~mm}$. This is confirmed by genetic analysis using the PCR diagnostic method (polymerization of chain reactions).

\section{References}

1. V.A. Gaydar, J. Beekeeping, 9, 24-26 (2006)

2. V.A. Gaydar, J. Beekeeping, 6, 14-15 (2004)

3. N.I. Krivtsov, Keeping bee colonies with the basics of breeding, 396 (1995)

4. V.I. Lebedev, Agropromizdat, 239 (1991)

5. L.Ya. Moreva, I.A. Morev, J. Beekeeping, 3, 14-19 (2012)

6. Sh.R. Suyarkulov, J. Beekeeping, 6, 13-15 (2010)

7. E.M. Petrov, Bashkir bee, 216 (1980)

8. F.G. Yumaguzhin, Agricultural Sciences, 12, 18-20 (2012)

9. R.A. Ilyasov, Bees for development, 114, 11-17 (2015)

10. R.A. Ilyasov, Wild dark honey bees of the Urals, 55, 27-32 (2015) 